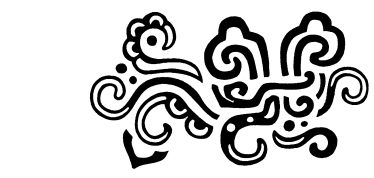

ZAPOTEC SCIENCE 
THIS PAGE INTENTIONALLY LEFT BLANK 


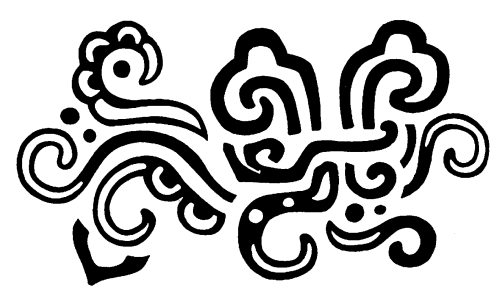

\title{
ZAPOTEC SCIENCE
}

\author{
Farming and Food \\ in the Northern Sierra \\ of Oaxaca
}

Roberto 7. González

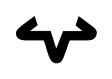

University of Texas Press

Austin 
Copyright $\odot$ 200I by the University of Texas Press All rights reserved

Printed in the United States of America First edition, 200I

Requests for permission to reproduce material from this work should be sent to Permissions, University of Texas Press,

P.O. Box 7819, Austin, TX 78713-78rig.

(2) The paper used in this book meets the minimum requirements of ANSI/NISO Z39.48-I992 (RI997)

(Permanence of Paper).

Library of Congress Cataloging-in-Publication Data

González, Roberto J. (Roberto Jesús), 1969-

Zapotec science : farming and food in the Northern Sierra of Oaxaca / Roberto J. González. - ist ed.

p. $\mathrm{cm}$.

Includes bibliographical references and index. ISBN 0-292-7283I-X (hardcover : alk. paper) ISBN 0-292-72832-8 (paperback : alk. paper)

I. Zapotec Indians-Agriculture. 2. Zapotec Indians-Food. 3. Traditional farming-Mexico-San Miguel Talea de Castro. 4. Subsistence economy-Mexico-San Miguel Talea de

Castro. 5. Sustainable development-Mexico-San Miguel Talea de Castro. 6. San Miguel Talea de Castro (Mexico)Social life and customs. I. Title.

$$
\begin{gathered}
\text { FI22I.Z3 G66 200I } \\
630^{\prime} .972^{\prime} 74-\mathrm{dc} 2 \mathrm{I}
\end{gathered}
$$

oo-OI2OIO 
A los que han compartido sus conocimientos-

Roberto J. González, Jr., Imelda F. González,

Laura Nader,

Rodolfo Bautista Solís,

y los bhni buen dxin ibá de Ralb'a (los campesinos de Talea),

Juventino Chávez Méndez y su familia en especial. 